\title{
Effects of the Hippocampal Deep Brain Stimulation on Cortical Epileptic Discharges in Penicillin - Induced Epilepsy Model in Rats
}

\author{
Ratlarda Penisilinle Indüklenmis Deneysel Epilepsi Modelinde \\ Hipokampal Derin Beyin Stimülasyonun Kortikal İktal Aktivite Üzerine \\ Etkileri
}

Tarik AKMAN ${ }^{2}$, Haydar ERKEN ${ }^{3}$, Goksemin ACAR ${ }^{1}$, Elif BOLAT ${ }^{2}$, Zahir KIZILAY ${ }^{2}$, Feridun ACAR ${ }^{2}$, Osman GENC ${ }^{3}$

${ }_{1}^{1}$ Pamukkale University, Faculty of Medicine, Department of Neurology, Denizli, Turkey

${ }_{2}$ Pamukkale University, Faculty of Medicine, Department of Neurosurgery, Denizli, Turkey

${ }^{3}$ Pamukkale University, Faculty of Medicine, Department of Physiology, Denizli, Turkey

This study was presented at the Annual Scientific Congress of Turkish Neurosurgical Society, 14-18 May, 2010, Antalya, Turkey

Correspondence address: Goksemin ACAR / E-mail: goksemind@yahoo.com

\begin{abstract}
AIM: Experimental and clinical studies have revealed that hippocampal DBS can control epileptic activity, but the mechanism of action is obscure and optimal stimulation parameters are not clearly defined. The aim was to evaluate the effects of high frequency hippocampal stimulation on cortical epileptic activity in penicillin-induced epilepsy model.

MATERIAL and METHODS: Twenty-five Sprague-Dawley rats were implanted DBS electrodes. In group-1 ( $\mathrm{n}=10$ ) hippocampal DBS was off and in the group-2 ( $n=10)$ hippocampal DBS was on $(185 \mathrm{~Hz}, 0.5 \mathrm{~V}, 1 \mathrm{~V}, 2 \mathrm{~V}$, and $5 \mathrm{~V}$ for $60 \mathrm{sec})$ following penicillin $\mathrm{G}$ injection intracortically. In the control group hippocampal DBS was on following $8 \mu \mathrm{l}$ saline injection intracortically. EEG recordings were obtained before and 15 minutes following penicillin-G injection, and at 10th minutes following each stimulus for analysis in terms of frequency, amplitude, and power spectrum.

RESULTS: High frequency hippocampal DBS suppressed the acute penicillin-induced cortical epileptic activity independent from stimulus intensity. In the control group, hippocampal stimulation alone lead only to diffuse slowing of cerebral bioelectrical activity at $5 \mathrm{~V}$ stimulation.

CONCLUSION: Our results revealed that continuous high frequency stimulation of the hippocampus suppressed acute cortical epileptic activity effectively without causing secondary epileptic discharges. These results are important in terms of defining the optimal parameters of hippocampal DBS in patients with epilepsy.
\end{abstract}

KEYWORDS: Penicillin-induced, Epilepsy, Hippocampus, Deep brain stimulation, Parameter

öz

AMAÇ: Deneysel ve klinik çalışmalar hipokampal DBS'nun epileptik aktiviteyi kontrol edebildiğini göstermektedir, ancak etki mekanizması ve optimal stimulasyon parametreleri açıkça bilinmemektedir. Bu çalışmanın amacı, penisilinle indüklenmiş deneysel epilepsi modelinde hipokampusun yüksek frekanslı uyarılmasının kortikal iktal aktivite üzerindeki etkilerini araştırmaktır.

YÖNTEM ve GEREÇ: Yirmi beş Sprague-Dawley rata hipokampal derin beyin elektrodu yerleştirildi.Grup-1 ( $n=10$ )'de intrakortikal penisilin G enjeksiyonundan sonra hipokampal DBS kapalı kaldı. Grup-2 $(n=10)$ 'de intrakortikal penisilin $\mathrm{G}$ enjeksiyonundan sonra, kontrol grubu $(n=5)^{\prime}$ nda ise intrakortikal $8 \mu \mathrm{l}$ salin enjeksiyonundan sonra hipokampal DBS açık tutuldu $(185 \mathrm{~Hz}$, kademeli artan uyarı şiddeti ;0.5, 1V, 2V, 5V, uyarı süresi 60 sn). Deneklerin EEG kayıtları Penisilin G/salin enjeksiyonundan önce, sonraki 15. dakikada ve her bir hipokampal uyarıdan sonraki 10. dakikalarda elde edildi. EEG kayıtları frekans, amplitüd ve güç spektrumu açısından analiz edildi.

BULGULAR: $185 \mathrm{~Hz}$ frekansında hipokampal DBS'nun penisilinin indüklediği akut kortikal iktal aktiviteyi uyarı şiddetinden bağımsız olarak baskıladığı görüldü. Kontrol grubunda artan şiddetlerde uygulanan hipokampal DBS'nun epileptik deşarj oluşturmadığı, yalnızca 5V uyarı sonrasında serebral biyoelektrik aktivitenin yaygın olarak yavaşladığı görüldü.

SONUÇ: Bu çalışmanın sonuçları hipokampusun sürekli yüksek frekansta uyarılmasının akut kortikal iktal aktiviteyi yeni epileptik deşarjlara yol açmadan etkin bir biçimde baskıladığını göstermektedir. Bu sonuçlar epilepsi tedavisinde yeni bir yöntem olan hipokampal DBS'de optimal stimulasyon parametrelerinin belirlenmesine katkıda bulunacaktır.

ANAHTAR SÖZCÜKLER: Penisilin, Epilepsi, Hipokampus, Derin beyin stimulasyonu, Parametre 


\section{INTRODUCTION}

Despite many alternatives of antiepileptic drugs, up to $30 \%$ of patients with epilepsy will suffer poor seizure control from maximal therapy. (7) Approximately $60 \%$ of these patients are candidates for resective surgery. (14) Patients who are not suitable for resective surgery, vagus nerve stimulation, a form of neuromodulation therapy, may provide additional benefit in combination with medical treatment that is greater than $50 \%$ reduction in seizure frequency. (3) Another form of neuromodulation is deep brain stimulation. The significant experience of DBS in movement disorders in view of its advantages such as titratability, reversibility and safety led researchers to investigate its use in epilepsy treatment. In selected patients, DBS of several targets in the central nervous system, such as caudate nucleus, anterior nucleus of the thalamus, cerebellum, hippocampus and subthalamic nucleus resulted in seizure reduction. $(6,13,15)$ Although the underlying mechanism of action of DBS is obscure, some evidence suggests that the most likely mechanism may involve stimulation induced modulation of the pathological neural networks. $(8,10)$ Inhibition of the neurons immediately adjacent to the stimulation area is probably involved. The applied current may inhibit neurons with a pathologically lowered threshold of activation. Alternatively, DBS may act on neural network projections to nearby or remote CNS structures originating from the area of stimulation.

Different stimulation parameters are investigated in experimental models of epilepsy. Epileptic activity is suppressed effectively with subthalamic nucleus DBS in rats with over $130 \mathrm{~Hz}$. (16) Stimulation of anterior nucleus of thalamus with $100 \mathrm{~Hz}$ in pentylentetrazole model of epilepsy in rats inhibited clinical seizures. (11) The results of therapeutic DBS to stop seizures varies according to the stimulation site and frequency applied. Amygdala and pyriform cortex kindled seizures are suppressed with slow $(1 \mathrm{~Hz})$ stimulation, however tuberomamillary DBS facilitated epileptic seizures with high frequencies $(60-100 \mathrm{~Hz}) .(2,5,20)$ The optimal treatment parameters are not clearly defined. Generally the parameters that are used for movement disorders are applied in the treatment of epilepsy with DBS.

In this study, the aim was to determine the effects of high frequency $(185 \mathrm{~Hz})$ hippocampal DBS with gradual increments of stimulus intensity on cortical epileptic discharges in a penicillin-induced epilepsy model in rats.

\section{MATERIAL and METHODS}

Twenty-five adult female Sprague-Dawley rats ( $175 \mathrm{gr}$ mean body weight) were enrolled in the study maintained under standard laboratory conditions (temperature $22{ }^{\circ} \mathrm{C}$; light/ dark cycle 12/12h; ad libitum availability of pellet food and water). Animal care ad all experimental procedures were in accordance with those detailed in NIH Guide for the Use and Care of Laboratory Animals. The animals were fully anesthetized with a combination of xylazine $(10 \mathrm{mg} / \mathrm{kg})$ and ketamine $(90 \mathrm{mg} / \mathrm{kg})$ intra-peritoneally. This study was approved by the local ethics committee.

\section{Electrode implantation and penicillin-G induced epilepsy model}

All of the animals were implanted hippocampal deep electrodes for stimulation with stereotactic methods. Under general anesthesia, the animals were placed in the stereotactic framer (Stoelting, UK) and a Teflon insulated stainless steel bipolar electrode was implanted to the right hippocampus via an occipital burr hole. The coordinates were $4,5 \mathrm{~mm}$ posterior and $3 \mathrm{~mm}$ lateral to bregma and $3 \mathrm{~mm}$ vertical from dura according to Paxinos and Watson's stereotactic atlas. (12)

The rats were randomly allocated to two groups; experiment group (EG) (500IU penicillin-G in a volume of $8 \mu \mathrm{l}$ injected intracortically, $n=20)$ and control group (CG) $(8 \mu$ l saline injected intracortically, $n=5)$. Penicillin-G or saline was injected to right primary motor cortex intracortically via stereotactic frame (coordinates: $0,7 \mathrm{~mm}$ anterior and $2 \mathrm{~mm}$ lateral to bregma and $2 \mathrm{~mm}$ vertical from dura according to Paxinos and Watson's stereotactic atlas. (12)

Following penicillin-G injection the EG was further allocated to two groups: EG-1 (hipocampal DBS off, $n=10$ ) and $E G-2$ (hippocampal DBS on; pulse stimulus $(5,35 \mathrm{msec}$ duration) with 10 min intervals, output current (OC): $0,5 \mathrm{~V}, 1 \mathrm{~V}, 2 \mathrm{~V}$ and $5 \mathrm{~V}$ for 60 seconds, $n=10$ ).

\section{EEG Analysis}

The epileptic activity was recorded and analyzed by Power lab system (Power Lab UK, 2000) before and after the hippocampal electrode implantation and penicillin-G injection. The recording parameters were as follows: $0,3-50 \mathrm{~Hz}$ low and high frequency filter, $50 \mathrm{~Hz}$ notch filter, recording speed $30 \mathrm{~cm} / \mathrm{sec}$.

Thirty second recordings free from artifacts were selected as the samples of spike/cortical activity and reaction to increasing stimulus intensities, at 15 th minute after penicillin$\mathrm{G}$ injection and 10 th minute following each stimulus $(0,5 \mathrm{~V}, 1 \mathrm{~V}$, $2 \mathrm{~V}$, and $5 \mathrm{~V}$ ).

The EEG signals obtained from these samples were analyzed according to frequency and amplitude. In addition to this, the power spectrum analysis was performed by fast Fourier transformation (software, Chart ${ }^{\mathrm{T}} 5.2 .2$, eDAQ).

\section{Statistical Analysis}

In the statistical analysis, the paired samples t-test was used for related samples and Mann-Whitney-U and Friedman's twoway analysis of variance was applied for unrelated samples. $P$ values smaller than 0.05 were statistically significant. The power spectrums were analyzed by one way ANOVA test and Tukey test was applied for post-hoc analysis (SPSS 16.0 version).

\section{RESULTS}

The first epileptic discharges were observed in 3-7 minutes following penicillin- $G$ injection and reached their maximum in approximately 15 minutes. The EEG recording lasted 60 minutes. (Figure 1-3) 


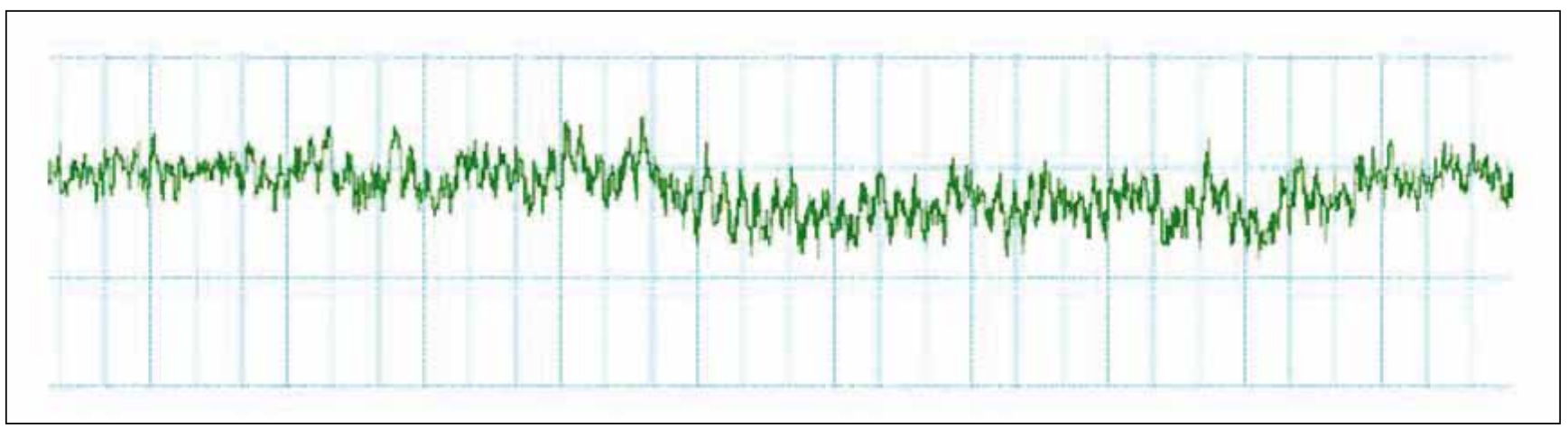

Figure 1: Electroencephalographic record before penicillin-G injection. Normal cortical activity.

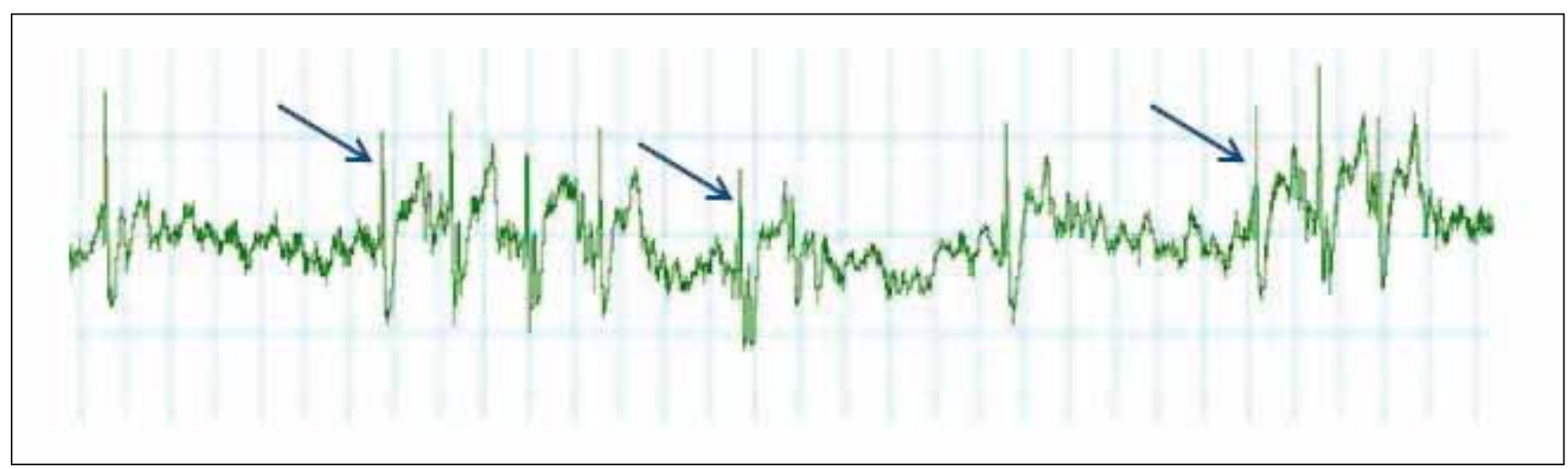

Figure 2: Spike discharges (arrows) are observed at 15th min after penicillin-G injection.

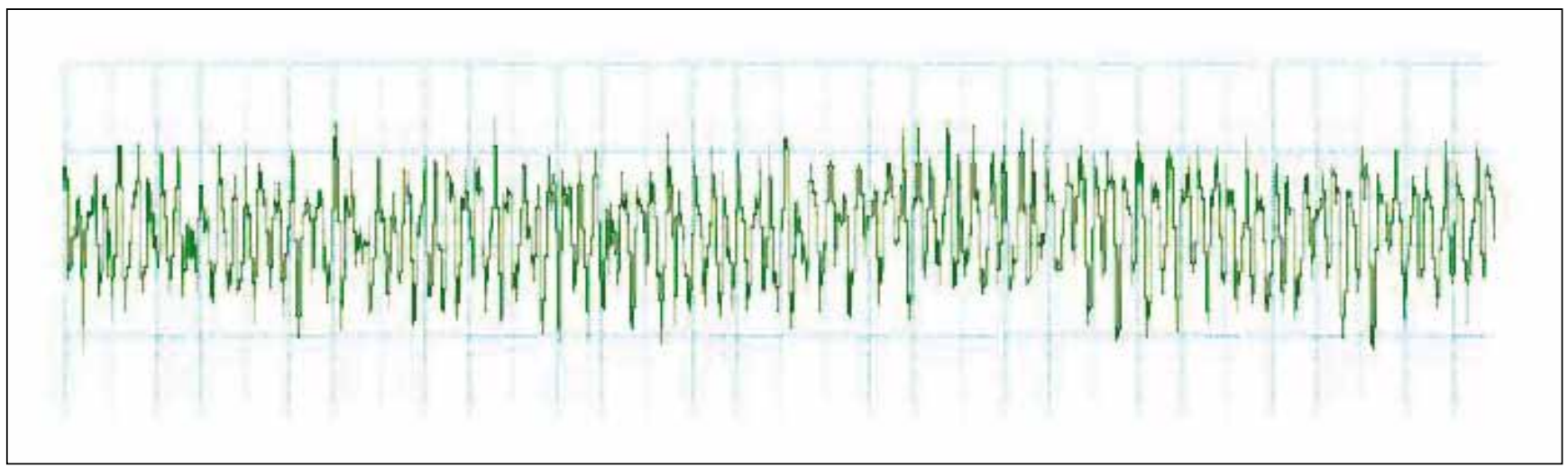

Figure 3: Electroencephalographic record during epileptic seizure with continuous spike activity.

In the EG-1, spike frequency was maintained at high levels throughout the experiment; however in EG-2 spike frequency was significantly reduced at each stimulus intensity $(p<0,005)$. (Figure 4) On the other the amplitudes did not change following the hippocampal stimulation.

The power spectrum analysis revealed that all of the stimulus intensities promoted significant reduction in cortical spike activity $(p=0,0001)$. (Figure 5$)$ Following $5 \mathrm{~V}$ hippocampal stimulus, the EEG activity was similar to those before the experiment. In EG-1, the significant increase in power spectrum was maintained all through the experiment. (Figure 5)
In the control group neither saline injection nor hippocampal stimulation caused epileptic discharges and seizures. However, following $5 \mathrm{~V}$ hippocampal stimulus a diffuse slowing in the cerebral bioelectrical activity was observed.

\section{DISCUSSION}

The neurostimulation therapies for epilepsy use primarily electrical stimuli of varying frequencies to impede epileptic activity. A variety of sites are approached to treat epilepsy, such as cerebellum, subthalamic nucleus, caudate nucleus, thalamus and hippocampus. These structures are either a part of the Papez circuit or have connections with it. Considering 


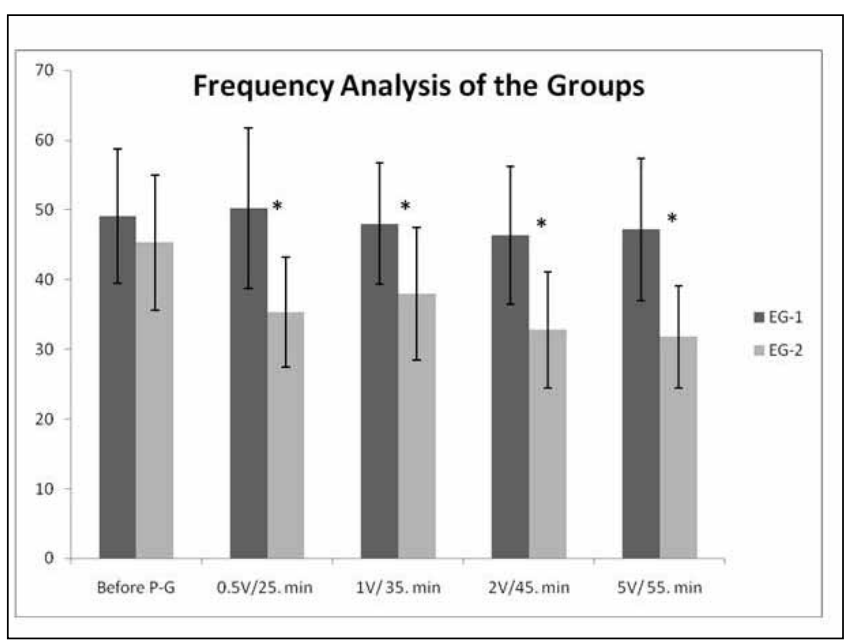

Figure 4: Frequency analysis revealed a significant decrease in the spike activity with hippocampal DBS (EG-2). ${ }^{*}: p<0,005$.

the role of Papez circuit in generation and propagation of the epileptic activity, interrupting the circuit can potentially prevent the generation and propagation of clinical and subclinical seizures with a well-tuned stimulation. Although the exact mechanism of neuromodulation is still obscure, the therapeutic stimulus can inactivate neurons by blocking depolarization and reducing the recruitment of the neurons in terms of the rhythmic epileptic activity they induce. (9) Moreover, neural stimulation can activate the inhibiting neurons and their projections, thus result in antiepileptic effect by changing the properties of the networks. (9) However, the significance of each of these mechanisms for the efficacy of therapeutic stimulation depends critically on the targeted region and on the stimulus parameters.

The experimental and clinical studies focusing on stimulation of some target regions such as subthalamic nucleus, caudate nucleus and cerebellum did not display satisfactory results in terms of seizure control. (9) However, the stimulation of anterior nucleus of thalamus, a relay station of the limbic system in close relation with both hippocampi and neocortex, can have an effect both on the epileptogenic focus and further spread of the epileptic activity. In a large controlled prospective multicenter study (SANTE), a significant reduction of seizure control was achieved in $54 \%$ of the patients. This safe and tolerable method of treatment is recommended in some patients with medically refractory partial and secondarily generalized seizures. (4)

Another rational target for epilepsy is the hippocampus considering the prevalence of mesial temporal lobe epilepsy (MTLE). In kindled rats, continuous $130 \mathrm{~Hz}$ stimulation of the hippocampus led to significant reduction in the excitability of the hippocampus. (21) Furthermore, high frequency stimulation at $130 \mathrm{~Hz}$ found to be more effective than low frequency in reducing the hippocampal excitability in epileptic rats. (22) In addition to these, small pilot studies have reported significant seizure reduction with hippocampal DBS in $70-90 \%$ of the patients with MTLE. $(1,17,19)$ In

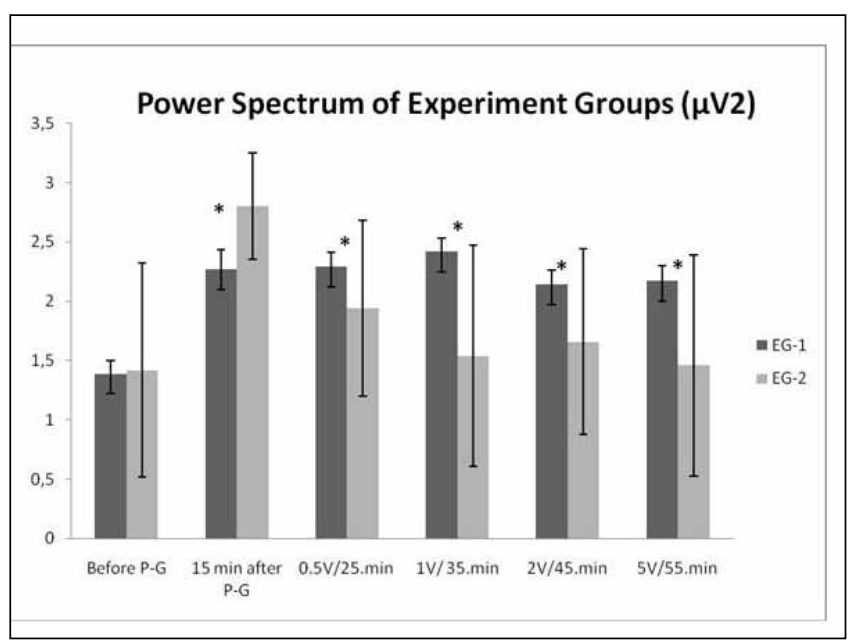

Figure 5: In this figure, the power spectrum at different stimulus intensities are demonstrated for both groups. A notable suppression of the power spectrum is evident in EG-2; ${ }^{*}: p=0,0001$.

these studies hippocampus was stimulated also at $130 \mathrm{~Hz}$ frequency. On the other hand, in the only double blind trial, 4 patients with MTLE are implanted DBS electrode in the hippocampus unilaterally and the continuous stimulation with $190 \mathrm{~Hz}$ resulted with no clear effect on seizure frequency. (16) As in evaluating anterior thalamic DBS, large controlled prospective studies are required to determine the safety and efficacy of hippocampal stimulation.

Admittedly the optimal stimulation parameters for treatment of epilepsy with hippocampal stimulation are not clearly defined and there is a trend to use similar stimulation parameters as used for the movement disorders. Another general opinion about DBS for epilepsy is that the clinical benefit would be obvious not as rapid as it is seen in movement disorders. By contrast, our study revealed that hippocampal stimulation with high frequencies $(185 \mathrm{~Hz})$ can effectively suppress the acute cortical epileptic discharges independent from the stimulus intensity. Moreover, the high frequency hippocampal stimulation did not promote epileptic discharges in non-epileptic control group. Hippocampal DBS seems to a safe and tolerable method of treatment in epilepsy, but the optimal stimulation parameters that are frequency, output current and stimulus duration are not clearly defined. Therefore, the results of this study are important in helping to set the parameters in patients with epilepsy treated with hippocampal DBS. In addition, the particularly acute spike suppressing effect of high frequency hippocampal DBS on remote seizure focus may help designing further studies focusing to clarify the exact mechanism behind the clinical benefits of this treatment.

Nevermore, further studies are required to determine whether the stimulus should target the origin of the seizure or subcortical structures, and whether the best seizure control can be achieved with open-loop stimulus or closedloop stimulus. 


\section{REFERENCES}

1. Boon $\mathrm{P}$,Vonck K: Deep brain stimulation in patients with refractory temporal lobe epilepsy. Epilepsia 48: 1551-1560, 2007

2. Carrington CA, Gilby KL, McIntyre DC:Effect of focal low-frequency stimulation on amygdala-kindled after discharge thresholds and seizure profiles in fast- and slow-kindling rat strains. Epilepsia. 48(8):1604-1613, 2007

3. DeGiorgio CM, Schachter SC, Handforth A, Salinsky M, Thompson J, Uthman B, Reed R, Collins S, Tecoma E, Morris GL, Vaughn B, Naritoku DK, Henry T, Labar D, Gilmartin R, Labiner D, Osorio I, Ristanovic R, Jones J, Murphy J, Ney G, Wheless J, Lewis P, Heck C: Prospective long-term study of vagus nevre stimulation for the treatment of refractory seizures. Epilepsia 41(9):1195-1200, 2000

4. Fisher R, Salanova V, Witt T, Worth R, Henry T, Gross R et al: Electrical stimulation of the anterior nucleus of thalamus for treatment of refractory epilepsy. Epilepsia 51:899-908,2010

5. Ghorbani P, Mohammad-Zadeh M, Mirnajafi-Zadeh J, Fathollahi $Y$ : Effect of different patterns of low-frequency stimulation on piriform cortex kindled seizures. Neurosci Lett 425(3):162-166, 2007

6. Halpern C, Hurtig H, Jaggi J, Grossman M, Won M, Baltuch G: Deep brain stimulation in neurologic disorders. Parkinsonism Relat Disord 13 (1): 1-16,2007

7. Kwan P, Brodie MJ: Early identification of refractory epilepsy. New England Journal of Medicine. 342:314-319,2000

8. Lee KH, Roberts DW, Kim U: Effect of high-frequency stimulation of the subthalamic nucleus on subthalamic neurons: An intracellular study. Stereotact Funct Neurosurg 80 (1-4): 32-36, 2003

9. Lega BC, Halpern CC,Jaggi JL, Baltuch GH: Deep brain stimulation in the treatment of refractory epilepsy:Update on current data and future directions Neurobiol Dis doi:10.1016/j.nbd.2009.07.007

10. McIntyre CC, Savasta M, Kerkerian-Le Goff L, Vitek JL: Uncovering the mechanism(s) of action of deep brain stimulation: Activation, inhibition, or both. Clin Neurophysiol 115 (6): 1239-1248,2004

11. Mirski MA, McKeon AC, Ferrendelli JA: Anterior thalamus and substantia nigra: Two distinct structures mediating experimental generalized seizures. Brain Res 397:377-380, 1986
12. Paxinos G, Watson C: The Rat Brain in Stereotaxic Coordinates. Orlando, FL: Academic Press, 1998

13. Rezai AR, Machado AG, Deogaonkar M, Azmi H, Kubu C, Boulis NM: Surgery for movement disorders. Neurosurgery 62 (Suppl. 2): 809-838,2008

14. Sander JW: The natural history of epilepsy in the era of new antiepileptic drugs and surgical treatment. Epilepsia 44 (Suppl. 1): $17-20,2003$

15. Schuurman PR, Bosch DA, Merkus MP, Speelman JD: Long-term follow-up of thalamic stimulation versus thalamotomy for tremor suppression. Mov Disord 23 (8):1146-1153

16. Tellez-Zenteno JF, McLachlan RS, Parrent A, Kubu CS, Wiebe S: Hippocampal electrical stimulation in mesial temporal lobe epilepsy. Neurology 66:1490-1494, 2006

17. Velasco AL, Velasco M, Velasco F, Menes D, Gordon F, Rocha L, et al: Subacute and chronic electrical stimulation of the hippocampus on intractable temporal lobe seizures: preliminary report. Arch Med Res 31:316-328, 2000

18. Vercueil L, Benazzouz A, Deransart C, Bressand K, Marescaux C, Depaulis A, Benabid AL: High-frequency stimulation of the subthalamic nucleus suppresses absence seizures in the rat: Comparison with neurotoxic lesions. Epilepsy Res 31 (1): 39-46, 1998

19. Vonck K, Boon P, Achten E, De Reuck J, Caemaert J: Long-term amygdalohippocampal stimulation for refractory temporal lobe epilepsy. Ann Neurol 52:556-565, 2002

20. Wu DC, Zhu-Ge ZB, Yu CY, Fang Q, Wang S, Jin CL, Zhang SH, Chen $Z$ : Low-frequency stimulation of the tuberomammillary nucleus facilitates electrical amygdaloid-kindling acquisition in SpragueDawley rats. Neurobiol Dis 32(1):151-156, 2008

21. Wyckhuys T, De Smedt T, Claeys P, Raedt R, Waterschoot L, Vonck K, Van den Broecke C, Mabilde C, Leybaert L, Wadman W, Boon $P$ : High frequency deep brain stimulation in the hippocampus modifies seizure characteristics in kindled rats. Epilepsia 48(8):1543-1550, 2007

22. Wyckhuys T, Raedt R, Vonck K, Wadman W, Boon P: Comparison of hippocampal Deep Brain Stimulation with high $(130 \mathrm{~Hz})$ and low frequency $(5 \mathrm{~Hz})$ on after discharges in kindled rats. Epilepsy Res 88(2-3):239-246, 2010 